\title{
MAPPING OF A Leishmania major GENE/LOCUS THAT CONFERS PENTAMIDINE RESISTANCE BY DELETION AND INSERTION OF TRANSPOSABLE ELEMENT
}

\author{
Adriano C. COELHO(1), Luiz R. O. TOSI(2) \& Paulo C. COTRIM(1)
}

\begin{abstract}
SUMMARY
Pentamidine (PEN) is an alternative compound to treat antimony-resistant leishmaniasis patients, which cellular target remains unclear. One approach to the identification of prospective targets is to identify genes able to mediate PEN resistance following overexpression. Starting from a genomic library of transfected parasites bearing a multicopy episomal cosmid vector containing wildtype Leishmania major DNA, we isolated one locus capable to render PEN resistance to wild type cells after DNA transfection. In order to map this Leishmania locus, cosmid insert was deleted by two successive sets of partial digestion with restriction enzymes, followed by transfection into wild type cells, overexpression, induction and functional tests in the presence of PEN. To determine the Leishmania gene related to PEN resistance, nucleotide sequencing experiments were done through insertion of the transposon Mariner element of Drosophila melanogaster (mosK) into the deleted insert to work as primer island. Using general molecular techniques, we described here this method that permits a quickly identification of a functional gene facilitating nucleotide sequence experiments from large DNA fragments. Followed experiments revealed the presence of a P-Glycoprotein gene in this locus which role in Leishmania metabolism has now been analyzed.
\end{abstract}

KEYWORDS: Leishmania major; Pentamidine; Drug resistance; Gene transfection; Overexpression; Gene mapping; Transposable element.

\section{INTRODUCTION}

Leishmania is a flagellated protozoan and the causative agent of leishmaniasis, an human infection that can develop as cutaneous, mucocutaneous, or visceral lesions according to the mononuclear phagocyte system infected, parasite species or host susceptibility ${ }^{2,12}$.

Despite recent developments in the chemotherapy for leishmaniasis ${ }^{6}$, effective drug treatment remains difficult because of the many combinations of syndromes, the resistance of Leishmania species and the lack of adequate clinical trials. Antimony, the most effective agent to treat the disease is difficult to administer, present potential toxic effects and are considered expensive for large scale field regiments.

Few other antileishmanial drugs have been as extensively used as antimonials for treatment of leishmaniasis. Amphotericin B and Pentamidine (PEN) have generally been chosen as parenteral alternatives for human cases of poor response to the antimonial regimen. In spite of their toxic renal effects and the little knowledge of their mode of action in the parasite, these two agents are now being used with the benefit of new formulations or dosage regimens ${ }^{12,18}$.

A better understanding of the mode of action of these agents would bring new insights into the antileishmanial chemotherapy. From this perspective, the identification of parasite genomic loci involved in the development of resistance to these compounds might be of great value. Such approach is possible through the use of molecular techniques such as gene transfection, which employs specific shuttle vectors capable of replication within the parasite, as well as in bacteria. For instance, the vector cLHYG accepts up to $40 \mathrm{~kb}$ inserts of Leishmania genomic DNA and allows autonomous replication of molecules at a high copy number ${ }^{9,15,20}$. In previous work we demonstrated that resistance-related genes carried by cLHYG can be overexpressed under drug pressure, yielding specific drug resistance phenotypes in L. major Friedlin A1 strain $(\mathrm{LmFA} 1)^{5}$.

Here we describe the use of this overexpression/selection approach in the presence of PEN, and the mapping of isolated inserts aiming at functional gene identification.

\section{MATERIAL AND METHODS}

Parasite strains, cultures and drugs: Leishmania major strain Friedlin A1 (LmFA1) is a clonal avirulent line derived from the Friedlin V1 line (MHOM/IL/80/ Friedlin) after multiple passages in vitro ${ }^{7}$. Cells were grown in M199 media ${ }^{11}$, transfected by electroporation and plated

Abbreviations: ABC, ATP-binding cassette; kb, kilobase; LmFA1, Leishmania major Friedlin A1 strain; ORF, open reading frame; PEN, Pentamidine; PGP, P-glycoprotein. (1) Instituto de Medicina Tropical, Universidade de São Paulo, São Paulo, SP, Brasil.

(2) Departamento de Biologia Celular e Molecular e Bioagentes Patogênicos, Faculdade de Medicina de Ribeirão Preto, Universidade de São Paulo, Ribeirão Preto, SP, Brasil.

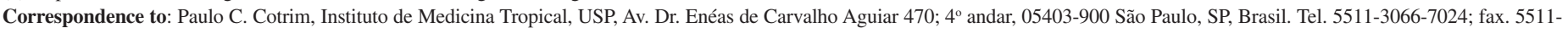
3062-3622. E-mail: pccotrim@usp.br 


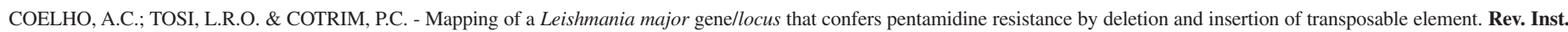
Med. trop. S. Paulo, 46(2):109-112, 2004.

on M199 semisolid media ${ }^{5,14}$, containing Pentamidine (PEN), obtained from Sigma Chemical Company (St. Louis, MO). For transfections of cosmids into Leishmania, plates contained $40 \mu \mathrm{g} / \mathrm{ml}$ of hygromycin B (HYG) were used for selection of transfected lines. To identify cosmidbearing lines exhibiting PEN resistance, $10^{6}$ wild type or cosmid-library transfected cells were plated on $100 \mathrm{~mm}$ M199 plates, containing increasing concentrations of the selective drug of interest. Macroscopic colonies were counted after 10-15 days of incubation, and recovered into M199 medium holding appropriate concentrations of selective drug.

Cosmid libraries and transfection: A library containing 30-40 kb inserts of Friedlin V1 genomic DNA were constructed into the E. coli Leishmania cLHYG shuttle vector as described ${ }^{20}$. Maxi preparation of cosmid library DNA was prepared by SDS/alkali lyses plus PEG precipitation and sterile DNAs were transfected into Friedlin A1 lines by electroporation, using 14-40 $\mu \mathrm{g}$ DNA per independent transfection and plating on M199 semi-solid media containing $40 \mu \mathrm{g} / \mathrm{ml} \mathrm{HYG}^{5,9,14,20}$.

Analysis of PEN resistance: PEN resistance of cosmid transfected cells were performed after DNA overexpression by successive passages in increasing concentrations of HYG up to $500 \mu \mathrm{g} / \mathrm{ml}^{5}$. Parasite numbers were determined using a Coulter Counter (model ZBI) after 2-3 days of incubation at $26{ }^{\circ} \mathrm{C}$. The inhibition concentration for $50 \%$ inhibition $\left(\mathrm{IC}_{50}\right)$ was defined as that drug concentration which resulted in a $50 \%$ decrease in cell number, measured at the time when control cultures lacking drug had reached late $\log$ phase (typically less than $\left.10^{7} / \mathrm{ml}\right)^{11}$. Experiment variations occurring during the tests were controlled by statistical tests for drug resistance utilized the parameter of fold resistance, defined as the average ratio of the experimental cell line $\mathrm{IC}_{50}$ divided by the wild-type $\mathrm{IC}_{50}$ measured in the same experiment, over $(n)$ independent experiments.

Molecular techniques: Cosmid DNA was recovered from a liquid culture with $10^{7}$ Leishmania cells by an alkaline-SDS lyses plus PEG precipitation, as described ${ }^{9,10,20}$. DNA was then transformed in $E$. coli (DH5- $\alpha$ strain) and isolated from these cells by SDS/alkali-phenol extraction and ethanol precipitation. Cosmid DNAs were first mapped by total digestion with restriction enzymes that have no sites within cLHYG vector DNA, like HindIII or EcoRV. Deletions were obtained by partial digestion with $0.1 \mathrm{U}$ of HindIII per $\mu$ g of cosmid DNA, followed by self-ligation also at partial conditions ${ }^{5}$.

Nucleotide sequencing strategy and reactions: To determine and facilitate the nucleotide sequence of the gene related with PEN resistance, random transposon insertion pools using the mos $K$ mariner transposable element ${ }^{21}$. For sequencing reactions, a PCR-based reaction kit was done with Thermo Sequenase fluorescent labeled primer cycle sequencing kit with 7-deaza-dGTP (Amersham Pharmacia). DNA sequencing was done on an ALF Express System (Amersham Pharmacia) automated sequencing. Nucleotide sequence of DNA inserts containing the mariner $\operatorname{mos} K$ were done using the 5' and 3' ends of the transposable element as primers island with primers directed to these extremities: $\operatorname{mos} K \mathrm{~F} 5^{\prime}$ CCGAGAGAGATGGGAAAAATG-3' and $\operatorname{mos} K$ R 5'GGTTGACACTTCACAAGGTC-3'.

Analysis of the sequence was performed using the DNASTAR software (Madison, WI) and Clone Manager $5^{\mathrm{TM}}$. We also used for confirmation and final deduction of the nucleotide sequence of the coding region, comparison with the data from the Leishmania major Genome Project at Sanger Center Web Server (www.sanger.ac.uk).

\section{RESULTS}

Selection of cosmids containing loci capable of render Leishmania resistant to PEN was carried out after platting a LmFA1 transfectant cosmid library with increasing concentrations of PEN ( 8 to $27 \mu \mathrm{M})$. The number of colonies obtained was compared to that of a control consisting of parental or cLHYG transfected LmFA1 cells as previously described (Table I). Control experiments yielded parasite colonies up to $17 \mu \mathrm{M}$ PEN but not on higher concentrations. In contrast, LmFA1 cosmid library transfectants yielded 20 colonies on $23 \mu \mathrm{M}$ PEN. No colonies were observed at $27 \mu \mathrm{M}$ PEN. The cosmid DNAs from 7 colonies showing differential PEN survival were recovered and analyzed by restriction digestion. We were able to isolate two cosmid populations (cosPEN1-A and cosPEN1-B) presenting inserts related to the same locus, which was named PEN1.

Table 1

Differential recovery of colonies from cosmid transfectant library and parental cells (LmFA1) after plating on the indicated PEN concentrations

\begin{tabular}{ccc}
\hline $\begin{array}{c}\text { PEN } \\
\text { concentration }\end{array}$ & $\begin{array}{c}\text { LmFA1 } \\
\text { cells }\end{array}$ & $\begin{array}{c}\text { Cosmid library } \\
\text { transfectants }\end{array}$ \\
\hline $27 \mu \mathrm{M}$ & 0 & 0 \\
$23 \mu \mathrm{M}$ & 0 & 20 \\
$17 \mu \mathrm{M}$ & 10 & 312 \\
$13 \mu \mathrm{M}$ & 200 & 800 \\
$12 \mu \mathrm{M}$ & 500 & 1000 \\
$8 \mu \mathrm{M}$ & 500 & $>1000$ \\
No PEN & $>1000$ & $>1000$ \\
\hline
\end{tabular}

Both cosmid DNAs were transfected back into LmFA1 cells to confirm their role in PEN resistance, and we could observe that transfected cells present statistical significant levels of PEN resistance when compared to LmFA1 wild type cells ${ }^{4}$.

The PEN1 locus was mapped by restriction analysis. The DNAs of cosPEN1-A (with an insert of approximately $25 \mathrm{~kb}$ ), and cosPEN1-B (with approximately $32 \mathrm{~kb}$ ) were digested with five restriction enzymes. The representation of Hind III prototype cosmid maps is shown in Fig. 1A. It is noteworthy that cosPEN1-A is a "natural" deletion of cosPEN1$\mathrm{B}$, being entirely contained within the latter. In order to limit the resistance phenotype locus (Fig. 1A), the smaller cosPEN1-A was used to produce deletions by partial digestion with HindIII, followed by self-ligation. The deletion cosPEN1-A $\triangle H$ HindIII, with an insert of approximately 15 $\mathrm{kb}$, was the only construct that remained able to render PEN resistance after transfection (Fig. 1A). A second set of deletions using EcoRV partial digestion was generated from cosPEN1-A $\triangle$ HindIII, and none confers PEN resistance after transfection, suggesting that the gene contains an internal EcoRV site. A $5 \mathrm{~kb}$ SalI fragment from cosPEN1-A $\triangle$ Hind III DNA was subcloned into the shuttle vector pSNBR (Fig. 1A) ${ }^{3}$. The resulting construct was named $\mathrm{pSNBR} / 5 \mathrm{~kb}$ SalI and did not confer PEN resistance after transfection into parental LmFA1 cells ${ }^{4}$. 
Primer island sequencing was used to characterize the construct $\mathrm{pSNBR} / 5 \mathrm{~kb}$ SalI. The mariner mosK in vitro transposition system was used to generate random transposon insertion into the target $\mathrm{DNA}^{21}$. The transposable element used (mosK) carries the Tn903 kanamycin resistance gene and allows the selection of insertion events following transformation into $E$. coli. Initially, $\operatorname{mos} K$ insertions were mapped by HindIII restriction analysis in order to determine the position of the transposon insertions along the $5 \mathrm{~kb}$ plasmid DNA. The presence of two HindIII sites within the target DNA and one HindIII site within the transposable element allowed the discrimination between insertion events that occurred into the cloned fragment and those in the vector backbone DNA (Fig. 1B).

Specific primers located at the 5'- and 3'-ends of the transposon were used in the sequencing of insertion events (Fig. 1B). The sequence generated from mos $K$ insertions was assembled into a fragment of 4,787 bp corresponding to the total DNA insert of the construct $\mathrm{pSNBR} / 5$ $\mathrm{kbSalI}$ (GenBank TM accession number AY251609). The 5'-end of the insert contains an open reading frame (ORF) of 3,696 nucleotides, which codes for a 1,232 amino acids (Fig. 1B), and was named Pentamidine Resistance Protien-1 (PRP1).

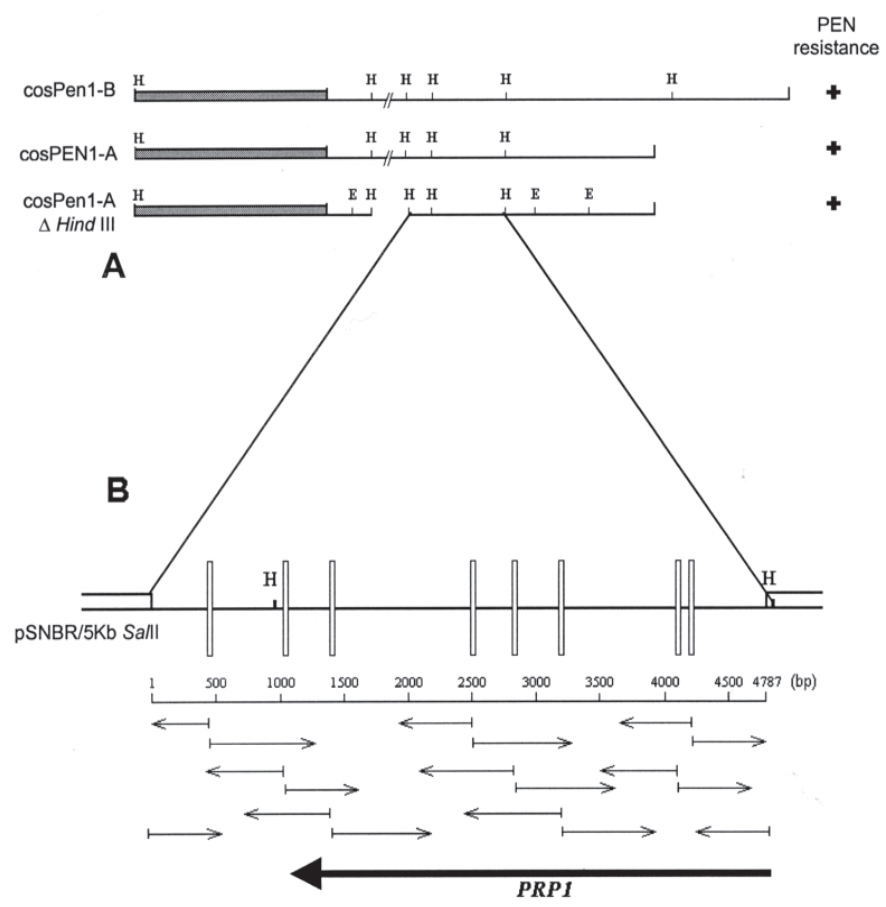

Fig. 1 - (A) Linear representation of the two related cosmids and the correspondent deletion that confer PEN resistance after transfection (+). H, Hind III; E, Eco RV. (B) Representation of the different insertions of mosK elements into the pSNBR/5 Kb SalI insert. Vertical rectangles correspond the location of each $\operatorname{mos} K$ elements. Arrows indicate the sequenced region starting from each transposon or from the plasmid. The positions of the base pairs are indicated. The large arrow indicates the open reading frame of 3,696 nucleotides (PRPI) contained in this insert. H, HindIII. E, EcoRV.

\section{DISCUSSION}

Southern blotting analysis revealed that the PEN1 locus is clearly distinct from those loci previously identified (data not shown), which are involved in the LmFA1 resistance to antifolates, nucleosides and sterol biosynthesis inhibitors ${ }^{5}$. Comparison of amino acid sequences in GenBank $^{\mathrm{TM}}$ through BLAST analysis ${ }^{1}$ revealed a significant identity with proteins belonging to the $\mathrm{ABC}$ ( $\underline{\mathrm{ATP}}-\underline{B}$ inding $\underline{\text { Cassette) }}$ transporters superfamily. In many organisms these proteins are involved in the transport of a variety of compounds through biological membranes ${ }^{13}$. The ABC transporters superfamily includes the P-glycoprotein (PGP) described in L. major and in other Leishmania species such as $L$. tarentolae and L. tropica, as well as in other trypanosomatids such as Trypanosoma cruzi $^{3,8,16,19}$. The nucleotide identity between PGPs of these organisms and the PRP1 described here varies from 30 to $40 \%{ }^{4}$. The comparative analysis also suggested that the predicted gene is not entirely contained within pSNBR/5 kb SalI plasmid insert due to a missing 5' portion. All PGPs from other trypanosomatids are coded by ORFs that are larger than the 3,696 bp found for PRP1. This confirms our observation that the $\mathrm{pSNBR} / 5 \mathrm{~kb}$ SalI construct was not able to confer PEN resistance to LmFA1 cells after transfection ${ }^{4}$.

The ABC transporter PGPA renders Leishmania resistant to heavy metals (arsenite and antimonials). Subcellular localization of PGPA in Leishmania revealed that the protein is present in intracellular membranes, suggesting that PGPA confers resistance to arsenite and antimonials by sequestration of metals into vesicles that could be exocytosed ${ }^{17}$. The elucidation of the role of the PRP1 in PEN sensitivity and/or resistance in Leishmania will not only contribute to the study of the ability of this organism to evade chemotherapy, but also to the design of effective treatments.

With the conclusion of the Leishmania genome sequencing project in a near future, the use of this new methodology for mapping and interrupting Leishmania gene/loci, can contribute enormously for gene identification as a practical tool for this new functional genomic era.

\section{RESUMO}

\section{Mapeamento de um gene de Leishmania major que confere resistência a pentamidina por deleção e inserção de elementos transposicionais}

A Pentamidina (PEN) é um composto alternativo para o tratamento de pacientes com leishmaniose que apresentam resistência ao antimônio, cujo alvo celular continua incerto. Uma abordagem para se identificar prováveis alvos seria a identificação e super-expressão de genes capazes de mediar resistência a PEN. A partir de uma genoteca construída com o DNA de Leishmania major em um vetor - cosmídio que se desenvolve tanto em bactérias como nas células do parasita, isolamos um locus que após transfecção é capaz de produzir resistência a PEN às células do parasita. Almejando o mapeamento desse locus de leishmania, o inserto clonado nesse cosmídio foi deletado através de duas digestões parciais sucessivas com enzimas de restrição, seguida de transfecção em células selvagens, super-expressão gênica, indução e testes funcionais na presença de PEN. Para determinar o gene de Leishmania relacionado com a resistência a PEN, o sequienciamento de nucleotídeos foi executado após inserção de elementos transposicionais de Drosophila melanogaster 
no interior do inserto deletado para atuar como 'ilhas de iniciadores'. Descrevemos aqui o mapeamento desse locus, após a inserção transposicional, que além de facilitar o seqüenciamento de nucleotídeos de grandes fragmentos de DNA, permite uma rápida identificação do gene relacionado com esse fenótipo. Experimentos posteriores revelaram neste locus a presença do gene de uma Glicoproteína-P de membrana, cujo papel no metabolismo na Leishmania está sendo analisado.

\section{ACKNOWLEDGEMENTS}

This work was supported by grants from The Pew Charitable Trust; TDR-WHO; FAPESP (95/9305-9, 97/00541-7, 02-09562-7; CNPq (to PCC and ACC) and LIM-48-FMUSP.

\section{REFERENCES}

1. ALTSCHUL, S.F.; GISH, W.; MILLER, W.; MYERS, E.W. \& LIPMAN, D.J. - Basic local alignment search tool. J. molec. Biol., 215: 403-410, 1990.

2. ASHFORD, R.W. - The leishmaniases as emerging and reemerging zoonoses. Int. J. Parasit., 30: 1269-1281, 2000.

3. CALLAHAN, H.L. \& BEVERLEY, S.M. - Heavy metal resistance: a new role for Pglycoproteins in Leishmania. J. biol. Chem., 266: 18427-18430, 1991.

4. COELHO, A.C.; BEVERLEY, S.M. \& COTRIM, P.C. - Functional genetic identification of PRP1, an ABC transporter superfamily member conferring pentamidine resistance in Leishmania major. Molec. biochem. Parasit., 130: 83-90, 2003.

5. COTRIM, P.C.; GARRITY, L.K. \& BEVERLEY, S.M. - Isolation of genes mediating resistance to inhibitors of nucleoside and ergosterol metabolism in Leishmania by overexpression/selection. J. biol. Chem., 274: 37723-37730, 1999.

6. CROFT, S.L. - Monitoring drug resistance in leishmaniasis. Trop. Med. Int. Hlth., 6: 899-905, 2001

7. DA SILVA, R.P. \& SACKS, D.L. - Metacyclogenesis is a major determinant of Leishmania promastigote virulence and attenuation. Infect. Immun., 55: 2802-2806, 1987.

8. DALlaGiOVANNA, B.; GAMARRO, F. \& CASTANYS, S. - Molecular characterization of a P-glycoprotein-related tcpgp2 gene in Trypanosoma cruzi. Molec. Biochem. Parasit., 75: 145-157, 1996.

9. DESCOTEAUX, A.; GARRAWAY, L.A.; RYAN, K.A. et al. - Identification of genes by functional complementation in the protozoan parasite Leishmania. In: ADOLPH, K.W., ed. Methods in Molecular Genetics. New York, Academic Press, 1994. p. $22-48$.
10. DESCOTEAUX, A.; TURCO, S.J.; SACKS, D.L. \& MATLASHEWSKI, G. - Leishmania donovani lipophosphoglycan selectively inhibits signal transduction in macrophages. J. Immunol., 146: 2747-2753, 1991

11. ELLENBERGER, T.E. \& BEVERLEY, S.M. - Multiple drug resistance and conservative amplification of the $\mathrm{H}$ region in Leishmania major. J. biol. Chem., 264: 15094 15103, 1989.

12. HERWALDT, B.L. - Leishmaniasis. Lancet, 354: 1191-1199, 1999.

13. HIGGINS, C.F. - ABC transporters: from microorganisms to man. Ann. Rev. Cell Biol., 8: $67-113,1992$.

14. KAPLER, G.M.; COBURN, C.M. \& BEVERLEY, S.M. - Stable transfection of the human parasite Leishmania major delineates a 30-kilobase region sufficient for extrachromosomal replication and expression. Molec. Cell Biol., 10: 1084-1094, 1990 .

15. LEBOWITZ, J.H.; COBURN, C.M.; McMAHON-PRATT, D. \& BEVERLEY, S.M. Development of a stable Leishmania expression vector and application to the study of parasite surface antigen genes. Proc. nat. Acad. Sci. (Wash.), 87: 9736-9740, 1990 .

16. LEGARE, D.; HeTteMA, E. \& OUELlETTE, M. - The P-glycoprotein-related gene family in Leishmania. Molec. Biochem. Parasit., 68: 81-91, 1994.

17. LEGARE, D.; RICHARD, D.; MUKHOPADHYAY, R. et al. - The Leishmania ATPbinding cassette protein PGPA is an intracellular metal-thiol transporter ATPase. J. biol. Chem., 276: 26301-26307, 2001

18. OLLIARO, P.L. \& BRYCESON, A.D.M. - Practical progress and new drugs for changing patterns of leishmaniasis. Parasit. today, 9: 323-328, 1993.

19. OUELLETTE, M.; FASE-FOWLER, F. \& BORST, P. - The amplified H circle of methotrexate-resistant Leishmania tarentolae contains a novel P-glycoprotein gene. EMBO J., 9: 1027-1033, 1990.

20. RYAN, K.A.; DASGUPTA, S. \& BEVERLEY, S.M. - Shuttle cosmid vectors for the trypanosomatid parasite Leishmania. Gene, 131: 145-150, 1993.

21. TOSI, L.R. \& BEVERLEY, S.M. - cis and trans factors affecting Mos1 mariner evolution and transposition in vitro, and its potential for functional genomics. Nucleic Acids Res., 28: 784-790, 2000.

Received: 1 October 2003

Accepted: 10 March 2004 